\title{
Incidence of Design-Based Research Methodology in Science Education Articles: A Bibliometric Analysis
} Incidência da Metodologia de Pesquisa Baseada em Design em Artigos de
Educação em Ciências: Uma Análise Bibliométrica

\author{
Luciana Natália Cividatti Bragueto, Vagner Antonio Moralles, Amadeu Moura Bego
}

Keywords Abstract The design-based research (DBR) methodology has been DBR, standing out in the field of educational research promising to adapt Bibliometrics, to different scenarios and boost the development of educational Scientometrics. innovations. However, 17 years after the beginning of the use of this methodology, there are still doubts about its potentiality. Given this, it is necessary to ascertain in which contexts this methodology has been used and what are the educational advances related to it. Thus, bibliometric mapping was carried out in this paper to generate indicators of studies on DBR, to indicate its relationship with the field of Science Education and situate Brazilian production in the international context. The study identified the distribution of publications by year, according to the number of publications, the main journals where these articles were published, the authors nationality, the most cited articles, the main keywords, and the network collaboration between authors. Data showed that the last five years have been the most promising for DBR publications and the North Americans were those who published more about this methodology. Despite the growing number of publications, the field of Science Education still makes little use of this methodology. The main applications found in DBR were related to teacher education, student motivation, and the use of information and communication technologies on teaching and learning. 
Palavras-chave Resumo A metodologia da pesquisa baseada em design (DBR) tem se DBR, destacado no campo da pesquisa educacional prometendo se adaptar Bibliometria, a diferentes cenários e impulsionar o desenvolvimento de inovações Cienciometria. educacionais. Porém, 17 anos após o início do uso dessa metodologia, ainda há dúvidas sobre sua potencialidade. Diante disso, é necessário averiguar em quais contextos essa metodologia tem sido utilizada e quais são os avanços educacionais a ela relacionados. O mapeamento bibliométrico foi realizado com o objetivo de gerar indicadores de estudos sobre DBR, indicar sua relação com a área de Educação em Ciências e situar a produção brasileira no contexto internacional. O estudo identificou a distribuição das publicações por ano, de acordo com o número de publicações, os principais periódicos onde esses artigos foram publicados, a nacionalidade dos autores, os artigos mais citados, as principais palavras-chave e a rede de colaboração entre os autores. Os dados mostraram que os últimos cinco anos foram os mais promissores para as publicações sobre DBR e os norte-americanos foram os que mais publicaram sobre essa metodologia. Apesar do número crescente de publicações, a área de Educação em Ciências ainda faz pouco uso dessa metodologia. As principais aplicações encontradas na DBR foram relacionadas à formação de professores, à motivação dos alunos e ao uso de tecnologias de informação e comunicação no ensino e aprendizagem.

\section{Introduction}

A frequent problem in teaching is the gap between theories developed in the academy and educational practices in real-life scenarios of schools. In search of alternatives to reduce this dichotomy, Brown (1992) and Collins (1992), in independent research, proposed an approximation between design science and educational research (Wang \& Hannafin, 2005). The theory that emerged from this interaction was entitled as design experiments.

As stated by Collins (1992), design experiments allow us to confront two big problems of the research seeking educational innovations: I) the lack of a priori theory to guide classroom interventions that can be assessed for improvement; II) the need to compare various experiments in order to identify positive and negative aspects of different designs.

The potentialities and results of the first applications of design science in education stimulated the interest of several research teams, generating a series of methodology variations that received different denominations (Wang \& Hannafin, 2005). Among these variations, stand out the development research (Van den Akker, 1999), the design research (Edelson 2002), the formative research (Reigeluth \& Frick, 1999), and the developmental research (Richey et al., 2003). Van den Akker (1999) points out that in the literature it is 
also possible to find the terms: design studies, formative inquiry, formative experiments, formative evaluation, action research, and engineering research.

The variety of terms and the lack of consensus on methodologies has led a group of professors and researchers - funded by the Pennsylvania State University's Spencer Foundation to Christopher Hoadley's Advanced Studies Institute, titled Design-Based Research Collective (DBR-Collective) - to publish a manifesto in 2003 suggesting the use of the term Design-Based Research (DBR) for this line of research.

As described in the document, DBR-Collective (2003, p. 8), the DBR can be conceived as a:

[...] methodology that bridges theoretical research and educational practice. Viewing both the design of an intervention and its specific enactments as objects of research can produce robust explanations of innovative practice and provide principles that can be localized for others to apply to new settings. Design-based research, by grounding itself in the needs, constraints, and interactions of local practice, can provide a lens for understanding how theoretical claims about teaching and learning can be transformed into effective learning in educational settings (DBR-Collective, 2003, p. 8).

According to the collegiate, DBR has the potential to create new teaching and learning environments; develop contextualized theories on teaching and learning; advance and consolidate design knowledge; and increase human capacity for educational innovation (DBR-Collective, 2003).

In order to develop these potentialities, a good research on the DBR perspective should have the following characteristics: I) integrate the objectives of creating learning environments and developing theories; II) develop contextualized theories of teaching and learning; III) produce results that should be shared with researchers and teachers; IV) highlight how, when, and why a particular design worked in reaching specific objectives in a given context; V) take place in interactive cycles of development, implementation, analysis, and re-design (DBR-Collective, 2003; Plomp, 2013). However, it is pertinent to verify if and how these consensual characteristics are in fact considered in DBR researches and a bibliometric analysis can contribute to this investigation.

Bibliometric research has been gaining prominence in recent years; but it has been underutilized in many fields, although it provides a useful tool for assessing and measuring science. This technique can be used to understand subjects like "what are the main topics or the main research fields within a certain scientific domain, how do these topics or these fields relate to each other and/or how has a certain scientific domain developed over time" (Waltman, van Eck, \& Noyons, 2010, p. 629). Moreover, "they allow for the creation of visual maps that represent the scholarly activities and the relationships that exist in a given domain" (Assefa \& Rorissa, 2013, p. 2514).

Bibliometrics is a research field that allows examining the consistency of knowledge within and between subjects. Thus, this type of analysis has the advantage to facilitate the verification of: I) large data sets; II) trends in thematic areas; III) trends 
in journals; and IV) citations (less susceptible to manipulation) (Holden, Rosenberg, \& Barker, 2005). This type of analysis may show the researchers who have been outstanding in the production of certain subjects, as well as their collaborative networks, the most relevant themes, among other factors (Batagelj \& Cerinsek, 2013; Okubo, 1997;).

It is noteworthy that, according to Web of Science $\odot$ (WoS) records, the first work presenting a bibliometric analysis on science education was published in 2015 (Razera, 2015) and, since then, less than 10 works have been produced on this interface. It is interesting to analyse that, despite the fact that bibliometric methods are firmly established and integrate research evaluation methodology (Elleggard \& Wallin, 2015), the field of Science Education has not followed this advance.

The WoS database search using as a topic the terms "design-based research" AND "bibliometric" yielded no results, regardless of the period. This result indicated that a bibliometric research on DBR might be important in highlighting perspectives and trends about the subject (Diem \& Wolter, 2013; Shareefa \& Moosa, 2020). Therefore, the bibliometric mapping of the DBR theme can be used to evaluate the highly cited articles in this area, as they have a considerable influence in the field, and may even indicate future perspectives for researchers and educators (Zheng, 2015).

Considering that currently there is a lack of studies to reconcile this type of analysis and methodological research approaches in Science Education, this work intends to carry out a bibliometric mapping of publications on DBR in the literature between 2003 and 2019. Particularly, the aim of this study is to generate indicators of DBR studies from the WoS database, as well as point out the relationships between these indicators intending to build a DBR bibliometric profile, as well as situating the stage of Brazilian production in the international context. This bibliometric profile was built considering: I) the number of publications on the subject over the years; II) the journals in which these articles are generally published; III) the nationality of the authors involved in the research; IV) which are the most cited articles; V) the keywords most used in these works; and VI) the collaboration network between authors who study this methodology. In view of these aspects, an attempt was made to understand the incidence of Brazilian researchers in the field of DBR investigations, considering an international database.

\section{Methodology}

To produce bibliometric maps, it was chosen the use of VOSviewer, an open source software that is used mainly for the analysis of bibliometric networks. According to its manual (Van Eck \& Waltman, 2017), the construction of these networks requires the use of Web of Science, Scopus, PubMed, RIS, or Crossref JSON files. The database used in this investigation was WoS, a platform widely used for bibliometric analysis because it is a very valuable source of information and indicators, a large database, with quality of indexing, and recognized worldwide (Andrade, Romanelli, \& Pereira-Filho, 2019; Li, Rollins, \& Yan, 2018; Zhu \& Liu, 2020). Although the preference for a database can be influenced by a variety of factors, including availability of the data source, quality 
and coverage of the data and even the users' previous experience, many studies have mentioned WoS for academic reviews, highlighting its wide use in bibliometric studies (Zhu \& Liu, 2020). WoS has a multidisciplinary and extensive coverage of bibliographic data referring to important international and regional scientific journals around the world (Garfield, 2007), and it still provides an analytical tool that can be useful for outlining perspectives and particularities on a subject of interest.

The first step was to define which terms should be used for the research so that they could effectively represent the research interests and, therefore, the data used in this research was initially derived from a simple search for the term "design-based research" (Search 1), presented in the document produced by DBR-Collective (2003), in order to determine in which areas this term has been used. The study considered only documents published from 2003 (term proposal) to 2019 (year immediately previous to the search date).

The term was searched in the Topic field and the data collection in the article was performed considering the title, abstract, author's keywords, and keywords plus. A keyword plus is a unique WoS technology that provides additional search terms extracted from the titles of the article cited by the authors in their bibliographies and footnotes, leading to a larger number of relevant articles (Garfield, 1990).

In a second moment, using the same principles of the "Search 1", it was performed a new research using the terms "design-based research" AND "science education" OR "design-based research" AND "science teaching" (Search 2), trying specifically to raise data regarding the use of $\mathrm{DBR}$ in the field of Science Education. All searches were performed on Jun 06, 2020 in the WoS Core Colletion.

The research was predominantly quantitative, reasoned on bibliometric bases. There are varieties of bibliometric indicators that can be used. Among the variety of indicators available for the construction of the DBR bibliometric profile, it was decided to use: I) the number of publications (per year, by WoS category and by geographic distribution); II) the main journals; the most cited articles (between 2003 and 2019 and in 2019); III) and the analysis of the most used author's keywords.

Bibliometric (or scientific) mapping, based on the author's keywords and authorship collaboration, was based on the co-occurrence analysis performed by VOSviewer software (version 1.6.11) seeking to understand how the main keywords were related to the DBR. VOSviewer software uses the clustering technique to establish connections between the terms found (Van Eck \& Waltman, 2010).

\section{Results and Discussion}

\section{Bibliometric Review}

In this work, it was considered only articles published in journals to bibliometric analyses and other documents listed by WoS were disregarded. The "Search 1" returned 1038 documents of which 724 (69.7\%) were articles. Figure 1 shows the evolution in the 
number of publications on DBR, highlighting the progress of the publications in the two main categories of WoS. Figure 2, in turn, presents the results of "Search 2", in which, out of 65 documents, 53 (81.5\%) publications were selected.

Figure 1. Total article publications on WoS obtained from the "Search 1" and its correlation with the WoS two main categories tendency of growth

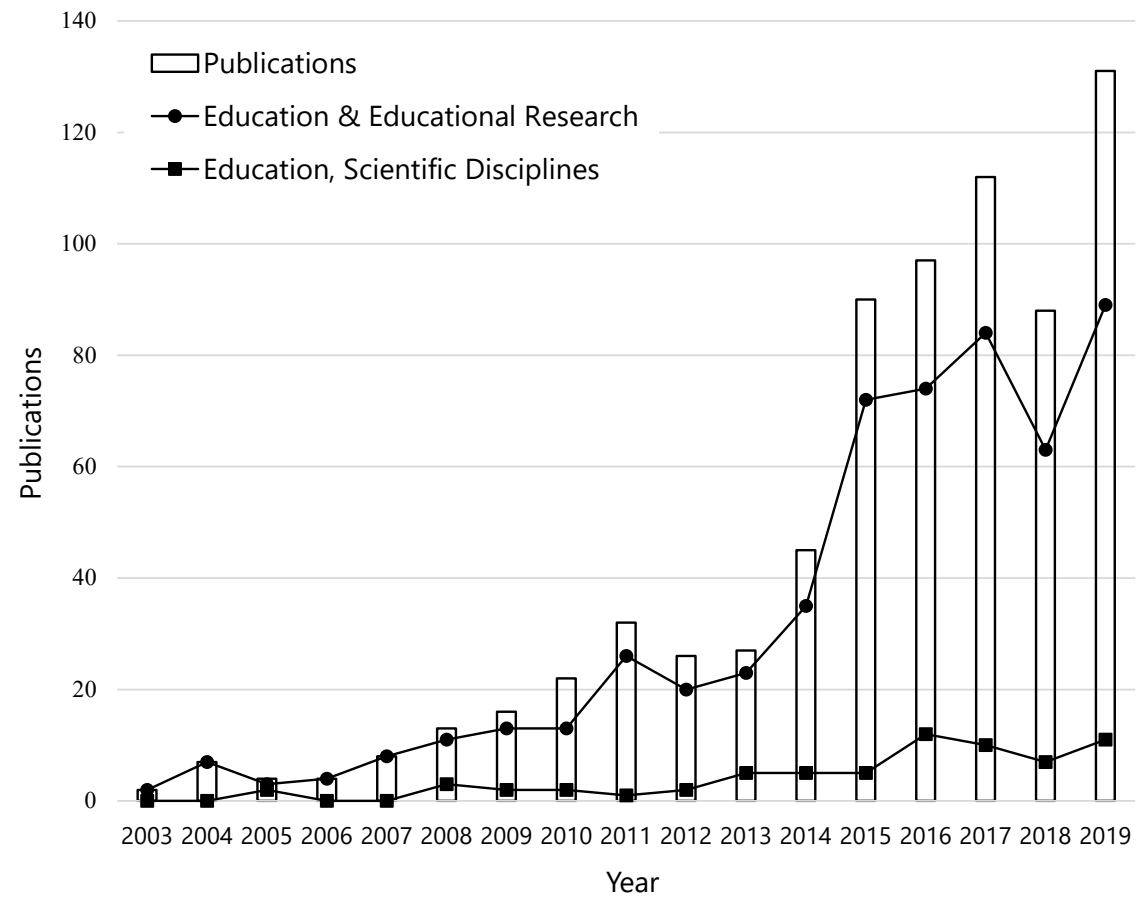

The analysis of Figure 1 indicates that there is a growth in the number of publications dealing with DBR, increasing from 2 in 2003 to 22 in 2010. Interestingly, the years between 2015 and 2019 were the most significant with regard to the number of publications on the subject, with an average of 103 articles per year. This result may indicate an important movement towards the development of a specific line of research on DBR within the Education field.

The "Search 1" results are divided into 71 different WoS classification categories, however the main category comprise over $75 \%$ of publications: "Education and Educational Research". Although the same article can be listed in two (or more) categories, since this classification depends on the journal in which it was published, these data indicate that, even if indirectly, most articles published between 2003 and 2019 on DBR are somehow related to the large area of Education. In addition, the growth in the number of publications in the "Education and Educational Research" category follows the growing trend in the number of DBR publications.

The results of "Search 2" are divided into 16 different WoS categories, and the main category also comprises over $75 \%$ of publications: "Education and Educational Research". Data show that when DBR is allied with Science Education, most publications are focused on teaching (or instructional) resources and strategies. 
Figure 2. Total article publications on WoS obtained from the "Search 2" and its correlation with the WoS two main categories tendency of growth

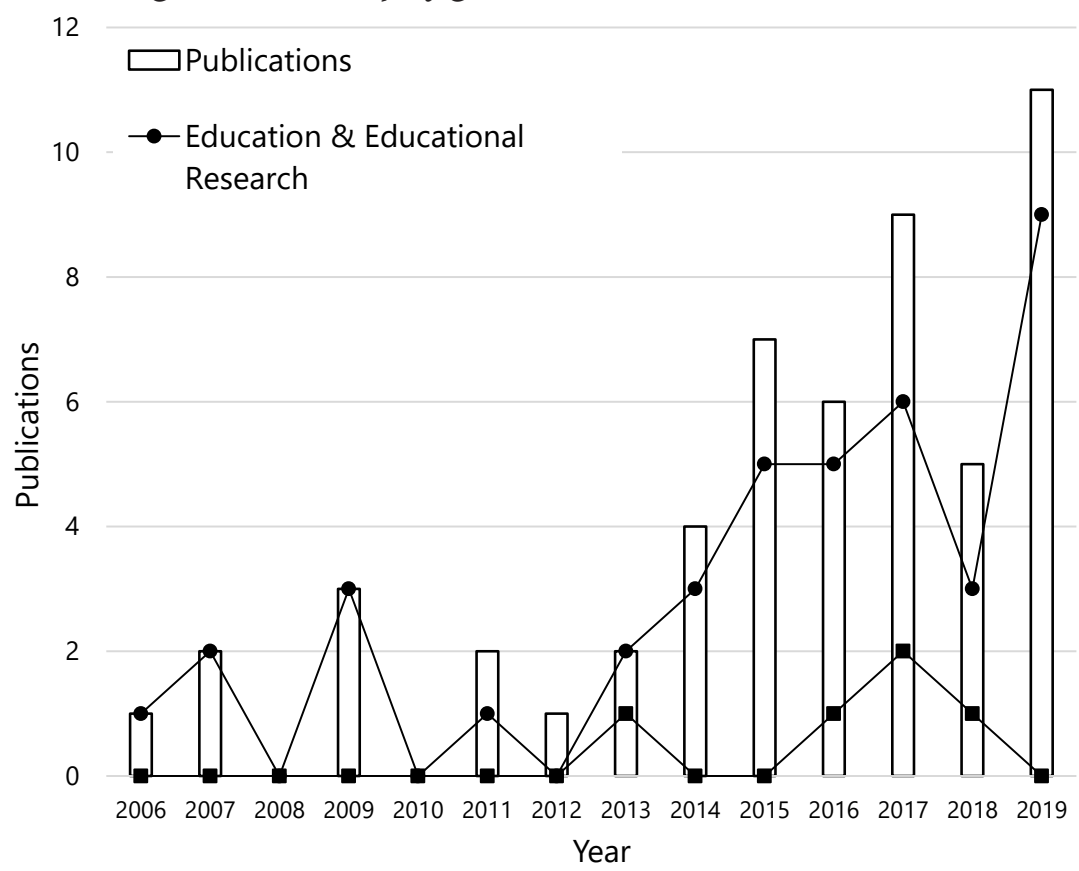

It is worth mentioning that only in 2006 the first article involving DBR and Science Education was released (25\% of the publications of the year mentioned). Although the number of publications on DBR and Science Education has grown in the last 5 years (2015-2019), reaching an average of 7.6 publications per year, these publications represent only $7.3 \%$ of the number of publications in the same period, when considering the broad publications about DBR. "Search 1" presented 327 different journal titles, but only 11 presenting 10 or more publications, totalling 174 publications ( $24 \%$ of the total). The "Search 2" presented 40 different journal titles, and 8 of them had 2 or 3 publications (21 publications, 39.6\%). Tables 1 ("Search 1") and 2 ("Search 2") show the respective journals with the largest number of publications.

Table 1. Journal classification by the articles amount obtained from the "Search 1"

\begin{tabular}{clc}
\hline Rank & Journal & $\mathbf{N P}^{\mathbf{a}}$ \\
1 & Educational Technology Research and Development & 21 \\
2 & Computers and Education & 20 \\
3 & Australasian Journal of Educational Technology & 19 \\
4 & British Journal of Educational Technology & 18 \\
5 & International Review of Research in Open and Distributed Learning & 16 \\
6 & Educational Technology and Society & 15 \\
8 & International Journal of Computer - Supported Collaborative Learning & 14 \\
9 & Journal of Science Education and Technology & 13 \\
10 & Cournal of the Learning Sciences & 12 \\
11 & Instructional Science & 11 \\
\hline${ }^{a}$ Number of publications.
\end{tabular}


Table 2. Journal classification by the articles amount obtained from the "Search 2"

\begin{tabular}{clc}
\hline Rank & Journal & NPa $^{\mathbf{a}}$ \\
\hline \multirow{3}{*}{1} & Cultural Studies of Science Education & \\
& Educational Technology Research and Development & 3 \\
& International Journal of Science Education & \\
& Journal of Research in Science Teaching & \\
& Science Education \\
& Journal of Experimental Education & \\
2 & Journal of Science Education and Technology & 2 \\
& Research in Science Education & \\
\hline
\end{tabular}

${ }^{a}$ Number of publications.

Research on DBR ("Search 1") was published by authors from 60 different nationalities: North Americans, Australians and Canadians were the researchers who published the most on the subject, being present in, respectively, 278 (38.4\%), 65 (9\%) and $48(6.6 \%)$ publications. It is also noteworthy that in 15 articles (5\%) there were North American and Canadian authors and in 3 articles (1\%) North American and Australian were co-authors. Brazilian researchers participated in the publication of only 9 of these articles, $1.2 \%$ of the total. The articles were published in 9 different journals.

About the scientific production of "Search 2", the authors were from 21 different countries, standing out North American and Canadian authors. North Americans are authors in 29 articles (54.7\%) and Canadians in 6 articles (11.3\%). It is emphasized that in 2 of these articles (3.7\%) North Americans and Canadians were co-authors. Only 1 of these articles was developed by two Brazilian women researchers. Their work (Batista \& Silva, 2019) was based on the development of experiment guides based on a historicalinvestigative approach, with DBR as a support methodology. The article presents some of the problems they faced in the implementation process, from the teacher's perspective, being, the majority, related to teacher working conditions and to school.

There is much controversy when considering the analysis of citations to evaluate the performance of a publication, because negative citations, self-citations and duplicates with homonyms are often included in this evaluation. Nonetheless, the citations can be considered as a measure of the article's impact, as well as its timeliness and usefulness (Okubo, 1997). The 10 most cited articles in the period were considered in our analyses, according to the WoS citation report. Table 3 presents the 10 most cited articles on DBR and Table 4 presents the most cited in the DBR and Science Education interface. Only the citations received for the works between 2003 and 2019 were considered, in both. 
Table 3. Ten most quoted articles obtained from "Search 1"

\begin{tabular}{|c|c|c|c|c|}
\hline Rank & Authors & Journal & Year & $\mathrm{NC}^{\mathrm{a}}$ \\
\hline 1 & Barab \& Squire & J. Learning Sciences & 2004 & 666 \\
\hline 2 & Wang \& Hannafin & $\begin{array}{l}\text { Educational Technology Research and } \\
\text { Development }\end{array}$ & 2005 & 498 \\
\hline 3 & Anderson \& Shattuck & Educational Researcher & 2012 & 400 \\
\hline 4 & Dunleavy, Dede \& Mitchell & J. Science Education and Technology & 2009 & 353 \\
\hline 5 & Marton \& Pang & J. Learning Sciences & 2006 & 220 \\
\hline 6 & diSessa \& Cobb & J. Learning Sciences & 2004 & 191 \\
\hline 7 & Vanderlinde \& van Braak & British Educational Research Journal & 2010 & 136 \\
\hline 8 & Amiel \& Reeves & Educational Technology and Society & 2008 & 130 \\
\hline 9 & $\begin{array}{l}\text { Fishman, Marx, Blumenfeld, } \\
\text { Krajcik \& Soloway }\end{array}$ & J. Learning Sciences & 2004 & 123 \\
\hline 10 & Barab, Gresalfi \& Ingram-Goble & Educational Researcher & 2010 & 113 \\
\hline
\end{tabular}

${ }^{a}$ Number of publications.

Table 4. Ten most quoted articles obtained from the "Search 2"

\begin{tabular}{|c|c|c|c|c|}
\hline Rank & Authors & Journal & Year & $\mathrm{NC}^{\mathrm{a}}$ \\
\hline 1 & Zembal-Saul. & Science Education & 2009 & 94 \\
\hline 2 & McNeill & J. Research in Science Teaching & 2011 & 73 \\
\hline 3 & Schwarz & Science Education & 2009 & 71 \\
\hline 4 & Grover, Pea \& Cooper & Computer Science Education & 2015 & 51 \\
\hline 5 & Ravenscroft & J. Computer Assisted Learning & 2007 & 49 \\
\hline 6 & Wang \& Reeves ${ }^{\star}$ & $\begin{array}{l}\text { Educational Technology Research and } \\
\text { Development }\end{array}$ & 2007 & 44 \\
\hline 7 & $\begin{array}{l}\text { Davis, Palincsar, Arias, Bismack, } \\
\text { Marulis, \& Iwashyna }\end{array}$ & Harvard Educational Review & 2014 & 41 \\
\hline 8 & Tiberghien, Vince \& Gaidioz & $\begin{array}{l}\text { International Journal of Science } \\
\text { Education }\end{array}$ & 2009 & 33 \\
\hline 9 & $\begin{array}{l}\text { Looi, Sun, Wu, Seow, Chia, Wong, } \\
\text { Soloway \& Norris }\end{array}$ & Computers and Education & 2014 & 32 \\
\hline 10 & $\begin{array}{l}\text { Rosebery, Warren \& Tucker- } \\
\text { Raymond }\end{array}$ & J. Research in Science Teaching & 2016 & 20 \\
\hline
\end{tabular}

Among the 10 most cited articles on DBR (Table 3), the most cited article (Barab \& Squire, 2004), entitled "Design-based research: Putting a stake in the ground", was published in the Journal of the Learning Sciences (9th journal with the largest number of publications on the subject). In addition, 3 other articles appearing in the top 10 were also published in this same journal. 
Further analysis of the 3 most cited articles on DBR shows that, in the most cited article (Barab \& Squire, 2004), the authors try to establish points of agreement on what really constitutes the DBR research, its importance and methods to accomplish it. The second most cited article (Wang \& Hannafin, 2005) proposes to discuss the importance, characteristics, future challenges, and principles for implementing DBR research. Finally, in the third most cited article (Anderson \& Shattuck, 2012), the authors review the characteristics of DBR and analyse the 5 most cited articles of each year in the first decade of the methodology implementation.

Considering the 3 most cited articles in the year 2019, some changes are noticed in relation to the citations received in the period between 2003 and 2019. One of the differences is that the 1st and 3rd positions are reversed. Another difference is that the work proposed by Dunleavy, Dede and Mitchell (2009), that assessed how teachers and students understand the ways in which participation in an augmented reality (AR) simulation influences teaching and learning, came to occupy the second place among the most cited. This data shows that the same articles have served as a reference for DBR over the years, indicating that they ended up being the seminal works of the line, substantiating and directing the investigative characteristics and perspectives of DBR. The fact that they are articles based on more theoretical data and with a strong bibliographic review component can be a prominent evidence in this regard.

Among the 10 most cited articles on DBR and Science Education (Table 4), the most cited article was published in 2009 (Zembal-Saul, 2009) under the title "Learning to teach elementary school science as argument" in the Sciende Education journal. This journal also published in the same year the 3rd most cited article entitled "Developing preservation elementary teachers' knowledge and practices through modelling-centered scientific inquiry" (Schwarz, 2009).

Analysing the 3 most cited articles on DBR and Science Education, the most cited one (Zembal-Saul, 2009) discusses the use of DBR by educators responsible for the pre-service teacher education. The second most cited paper (McNeill, 2011) aimed to investigate the explanations, arguments, and evidence of 5th graders in three contexts: what scientists do, what happens in classrooms of science, and what happens in everyday life. The third most cited article (Schwarz, 2009) also deals with teacher education and aimed, through DBR, to develop the knowledge and practices of pre-service teachers.

Considering only publications of 2019 , the most cited article in the period between 2003 and 2019 (Zembal-Saul, 2009) was transferred to the 3rd position among the most cited. In turn, the article that takes 1st place, titled "Designing for deeper learning in a blended computer science course for middle school students" (Grover, et al., 2015), describes a practical research conducted with students in a public school. The 2nd position, on the other hand, was taken by the article "Developing interpretive power in science teaching" (Rosebery et al., 2016), in which is presented a design research aimed at teachers' development, focused on early career professionals who teach science to students from historically non-dominant communities. When considering the period 
between 2003 and 2019, these articles were in positions 4th and 10th respectively and these data suggest that more recent articles have received more attention. These data also lead to believe that the science education field, as it still does not have much tradition on the topic, does not seem to follow the same trend as the education field (more consolidated) and, therefore, it is not yet possible to distinguish its seminal articles.

\section{Author's Keyword Analysis}

The keywords can legitimately reflect the authors' beliefs about the content fields of their articles. According to Baker (2004, p. 346), "an examination of dispersion patterns, concordances, and key clusters are useful supplementary forms of analysis". The choice of keywords that best demonstrate the characteristics of a given text is a qualitative judgment and the "comparative keyword analysis is therefore a conjoint qualitative and quantitative analytic method" (Seale, Charteris-Black, MacFarlane, \& McPherson, 2010, p. 598). Therefore, the author's keyword analysis can denote trends in a research field and even guide future research. This analysis was performed on the selected DBR articles (Search 1). The analysis indicated 1915 different keywords used in these publications and 346 of these (18.1\%) appeared twice, 170 (8.9\%) three times, 104 (5.4\%) four times, and $70(3,7 \%)$ five times or more.

The most used keywords in the articles were: "design-based research", with 235 occurrences (32.5\%); "design based research" (without hyphen), with 24 occurrences (3.3\%), and "mobile learning", with 22 occurrences (3\%). These data show that there is a diversity of research on DBR, since even the main keywords have few occurrences. Curiously, as presented, despite the significant increase in the publications number about DBR, the dispersion of occurrences might reveal that this is not a consolidated and well-established line in the Education area. Similarly, Grossman and McDonald (2008), discussing some problems on teaching and teacher education, assert that it is necessary for the researchers to start acting as part of a research collective with a common set of questions or concerns and ways consensual to generate new knowledge and organize and combine existing knowledge. In this context, a common language could serve as a powerful tool to bring together researchers and professionals involved in improving the line of research. This seems to be the scenario for research on DBR, since there is no clear trend in the use of keywords in the line. At last, finding the term "design-based research" (or "design based research") as the most common was expected, since it was used for the searches. It is also worth noting that WoS does not differentiate the terms with or without hyphen, since both generate the same results.

The DBR methodology has been increasingly applied to many fields, including Science Education (Davis et al., 2014; McNeill, 2011; Zembal-Saul, 2009), but this methodology still has a lot of potential to be explored. Although this term has appeared as one of the most used keywords by the authors, it has been used only 17 times, suggesting that this interface has been little explored in recent years.

The bibliometric mapping of the most frequent occurrences of author's keywords 
is shown in Figure 3. The figure shows a map in which the node size is proportional to the keyword's numbers of occurrence. The lines that interconnect nodes form networks in which the color indicates correlation between words, giving rise to clusters. For the construction of the bibliometric map, the author's keywords that appeared in at least 10 different articles were considered and the analysis (Figure 3) reveals the central terms for the topic "design-based research" and presents other derived terms. The terms were divided into clusters according to the co-occurrence and their association in the literature. Cluster 1 (red) shows terms related to teaching (instructional) methods. Cluster 2 (green) presents terms related to instructional strategies, focusing on learning and teacher education. The Clusters 3 (blue) and 4 (yellow) displays terms correlated to teaching, technology and evaluation.

If only articles with North American authors are considered, the most commonly used keywords (Search 1), in a universe of 821 different keywords, were "designbased research" (104 occurrences), "professional development" (12 occurrences), and "instructional design" (9 occurrences). The term "science education" appears in 4th place with 8 occurrences. Compared to Australians, with 197 different keywords, "design-based research" has 19 occurrences, followed by "pedagogy" (5 occurrences), and "teacher professional development" along with "teacher education" (4 occurrences). The term "science education" does not appear in this group of keywords. Regarding articles with Canadian authors, with 176 different keywords, "design-based research" has 18 occurrences and "instructional design" amongst "collaboration" and "professional development" with 3 occurrences each are the 2 nd. The keyword "science education" appears in the 3rd place, followed by another 11 keywords, with 2 occurrences each. When analysing articles with Brazilian authors, except for "design-based research" that was used in 4 different articles, the other 34 keywords appear in only one article each.

These data indicate that, although the research has grown in recent years, DBR applications are very diverse, once there is a predominance of different keywords in different countries and, even when considering a single country, the most used keyword occurrence is still very low.

When keyword analysis was performed for the "Search 2" publications, 162 different keywords were found, being that $22(13.6 \%)$ appeared twice, $10(6.2 \%)$ three times, 5 (3.1\%) four times, and $4(2.5 \%)$ five times or more. The keywords that most appeared in the publications were "design-based research", with 18 occurrences (34\%), "science education", with 17 occurrences (32.1\%), and "motivation" amongst "computer science education" with 5 occurrences each (9.4\%). The terms "science education" and "design-based research" were expected to emerge as the most used for the same reason explained previously in Search 1.

The "Search 2" bibliometric mapping made from the author's keywords that appeared in at least 3 different articles, since the number of articles analyzed in this case is lower (Figure 4) highlights the core terms for the DBR and Science Education interface and its derivations. 
Figure 3. Bibliometric mapping of the most frequent occurrences of author's keywords, obtained from the "Search 1"

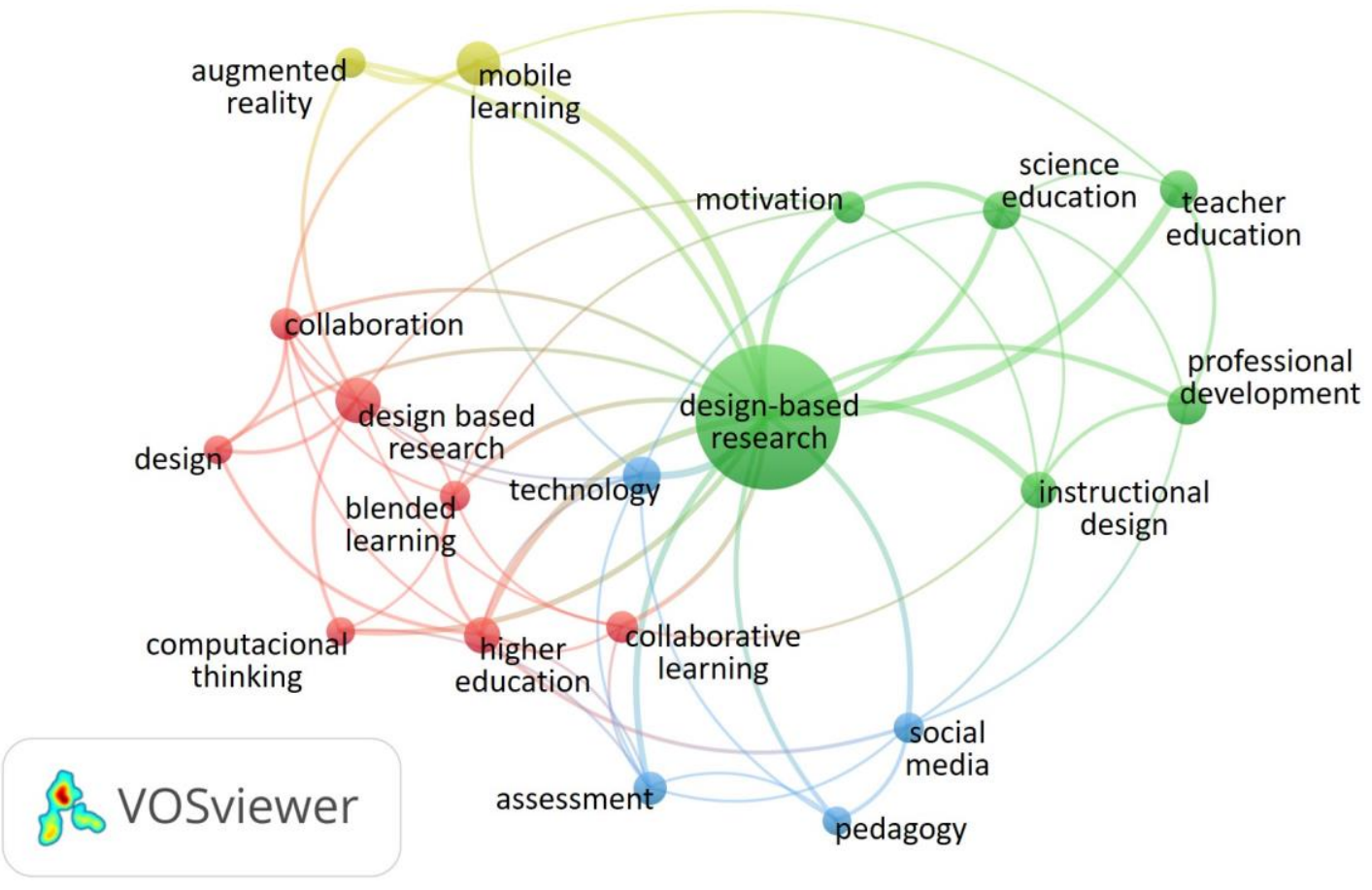

Figure 4. Bibliometric mapping of the most frequent occurrences of author's keywords, obtained from the "Search 2"

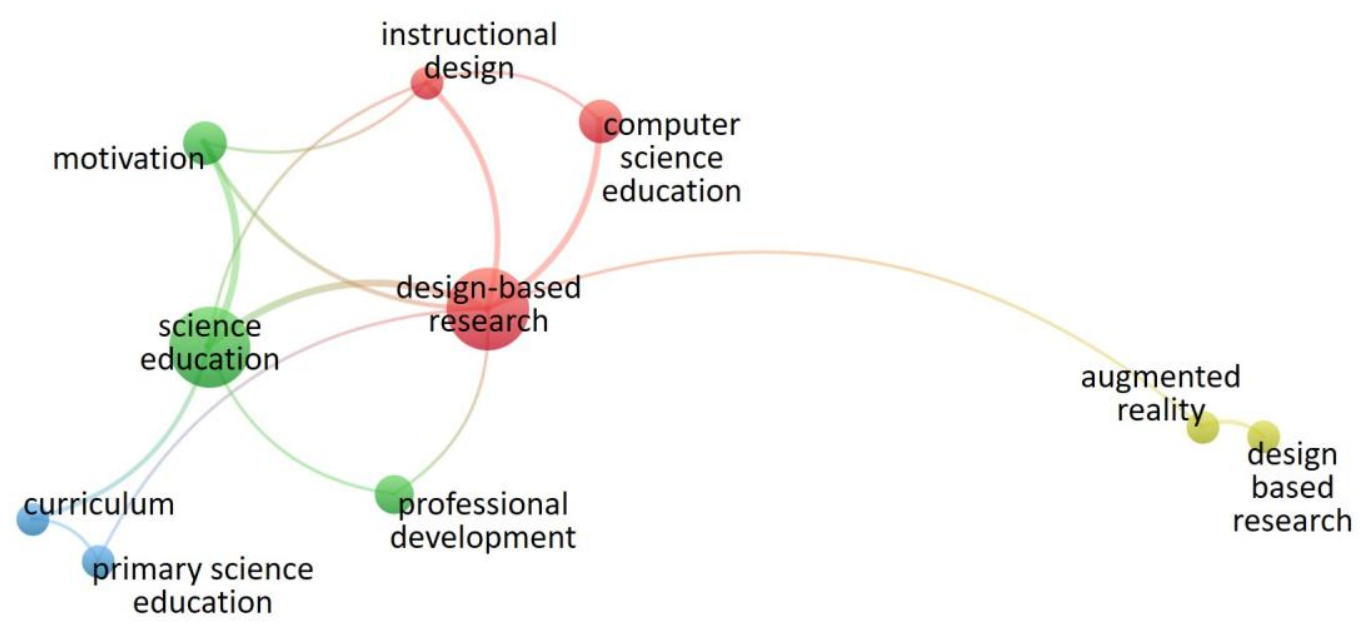

Cluster 1 (red) can be linked to the use of instructional strategies, including the use of technologies. Cluster 2 (green) presented terms related to motivation and science teacher education. Cluster 3 (blue) showed terms in the context of science teaching in the early years. Finally, the Cluster 4 (yellow) can be correlated with classroom technology use.

Considering the keywords most used by North Americans and Canadians, which 
are the most relevant for this subject (Search 2), the North Americans, in a universe of 99 different keywords, used "design-based research" (10 occurrences), "science education" (8 occurrences), and "computer science education" (5 occurrences each). The "science teaching" term appears as the 6th most used keyword (2 occurrences) with 4 other keywords. Canadians, in turn, with 22 different author keywords, the most used are "design-based research" (4 occurrences) and "science education" with "physics" (2 occurrences each). All the other keywords just appeared in one article.

Regarding the North Americans, it was noticed that other keywords that stand out are "professional development" (4 occurrences), "motivation" (3 occurrences each), and, lastly, "computational thinking", "instructional design" and "design", "case study" and "science teaching" (2 occurrences each), leading to believe that DBR and Science Education research are still very diverse (the other keywords had one occurrence each). However, it is already possible to verify that the studies have been related with the curriculum, the production of instructional strategies, professional development, and the student motivation, using DBR as an approach for implementation of proposals. On the other hand, about the Canadians authors keyword, only "physics" (besides "science education") appeared in 2 different articles (3.8\% of publications) and all the other keywords had only one occurrence, reinforcing the evidence that DBR studies are pretty diverse, even with the growth of the area, and the idea that there is a lack of articles that can support and direct the work done at the interface between DBR and science education.

\section{Authorship Analysis}

The "Search 1" authorship analysis shows that there were a total of 1777 authors who contributed to the articles. Among these, just 34 authors had collaboration links. It was observed that 5 authors collaborated in at least 5 articles and, of the 1777 authors, 192 of them contributed in at least 2 works, which indicates that $89.2 \%$ of related authors (1585) participated in a single publication. Among these 192 authors, just 13 had collaboration links. Figure 5 represents the collaboration network of these authors.

It should also be highlighted that, in terms of articles amount, Chee-Kit Looi (professor at the National Institute of Education, Singapore) and Jan Herrington (professor at Murdoch University, Australia) contributed to the largest number of publications ( 8 articles each one). However, despite Sasha Barab keeping 3 papers, one of his articles was the one that reached the highest number of citations among all selected (Barab \& Squire, 2004). It is noteworthy, however, that just Jan Herrington appears in the collaboration network between the authors (Figure 5).

There are three distinct groups of co-authoring groups when considering those who have published 2 or more articles. The author who stood out, in collaboration terms, was Jan Herrington (green cluster), contributing as a hub to the groups, with 8 publications. Jan Herrington has published these articles in collaboration with a set of co-authors, and she was the first author of two out of these articles.

Two other authors that stand out in Figure 5 are Thomas C. Reeves (blue cluster) 
and Thomas Cochrane (red cluster). Thomas C. Reeves, professor at the University of Wisconsin - Parkside (USA) published 6 articles, having been the first author of one of them. Thomas Cochrane, in turn, who is a professor at the University of Canterbury, New Zealand, also published 6 articles, and was the first author in two of them and single author in another.

Figure 5. Co-occurrence network of the collaboration of authors (Search 1) who participated in at least two publications

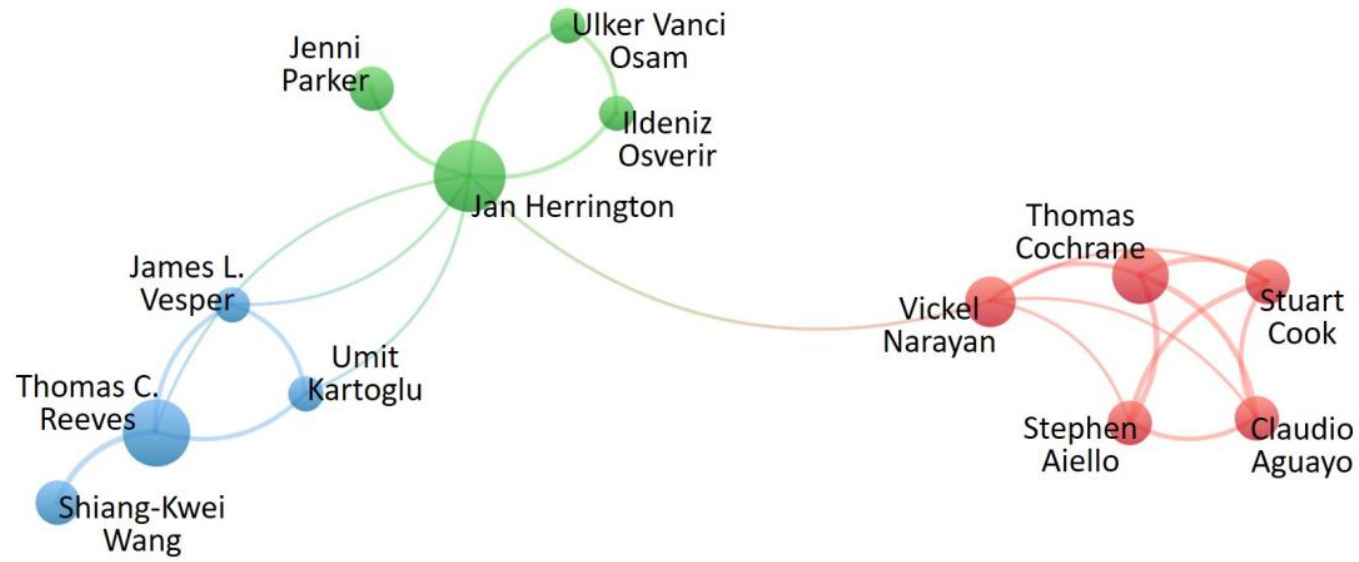

It should also be noted that both authors published articles with Jan Herrington. The work proposed by Vesper, Herrington, Kartoglu and Reeves (2015), in which Harrington and Reeves were co-authors, describes design elements to guide the development of e-learning prototypes for public health professionals. Likewise, the work of Narayan, Herrington and Cochrane (2019) explored how social media could facilitate a student-determined learning experience.

The Brazilian researcher Tel Amiel, a professor at the Faculty of Education in the University of Brasília, was the only Brazilian to have an article published in partnership with one of these authors who stand out in DBR scientific production. This work (Amiel \& Reeves, 2008), which is the 8th most cited of "Search 1" (Table 3), seeks to discuss the potential of design-based research as a framework to help ask the right questions in the educational technology research. According to these authors, if the argument for new design-based methodologies is strong, research and practice can intertwine and, as a result, it becomes impracticable to promote research that is impartial and uninvolved, research that dominates the literature currently.

Besides Amiel, another 16 Brazilian authors published about design-based research, and, of the 9 articles with Brazilian authors, 3 were made in partnership with other countries (France, New Zealand, and Portugal). The 17 Brazilian authors just have 1 publication each, and 53\% of them work in educational institutions in São Paulo state.

The "Search 2" authorship analysis shows that there was a total of 153 authors but just 9 authors had collaboration links. Figure 6 show the collaboration network of these authors. It was observed additionally that the authors collaborated with a maximum of 
2 articles and, even so, only 9 authors (5.9\%) are authors in 2 publications and, of these, only 4 published together.

Figure 6. Co-occurrence network of the collaboration of authors (Search 2)

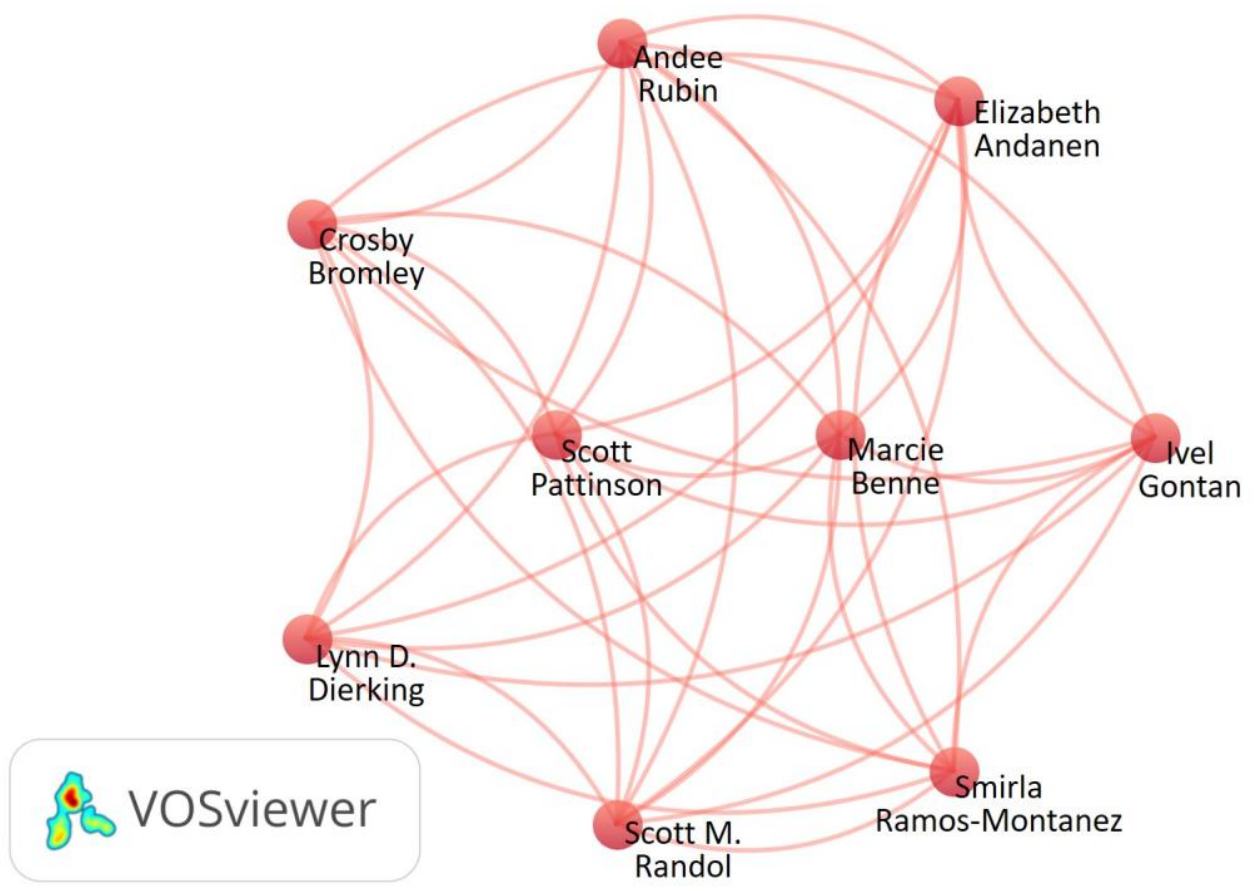

There is just one co-authoring network although all authors selected by the research are considered. As all authors have 1 or 2 publications, there is no one who stands out among the rest. When considering the collaboration network between the authors who published 2 articles, the only highlight is that, in this analysis the author Thomas C. Reeves appeared related to the author Shiang-Kwei Wang, as well as in the analysis of the results of "Search 1" (see Figure 5, blue cluster). Also, it can be pointed out that the author Chee-Kit Looi, who appeared as one of the most collaborators in articles on DBR, appears related to the author Lung-Hsiang Wong when the subject is the interface DBR and science education. It is worth mentioning that there are no Brazilian authors in these partnerships. The results lead to believe that there is still not a collaborative network between authors who are working with DBR and science education. These findings reinforce the argument of the initial phase of the research on the interface and lead us to agree with Grossman and McDonald (2008, p. 199), who point out the importance of researchers "to reach outside their immediate communities, to look over their backyards to see and learn from what their neighbors are doing", looking for ways to connect the researchers "across multiple subject areas and grade levels with the more general field of research on teaching”. Additionally, the authors argue that: "by speaking literally the same language, researchers can develop previous work and communicate their findings in a more powerful way, between themselves and with professionals" (p. 198). This is a challenge to be faced by science education researchers working in this emerging line of research. 


\section{Conclusions and Implications}

The result of the analysis indicates that DBR is attracting the attention of researchers around the world. The last five years were the most significant in terms of the increase of the number of publications on the subject, considering only DBR or considering papers in the interface with Science Education. It is realizable that the major part of DBR papers are linked to its use in order to study the intervention results related to other questions like teacher education, student motivation, and, specially, the use of technology in actual classroom context. In all cases, DBR not only enables, but also encourages the process of designing and redesigning educational interventions according to the research findings, which makes it a very flexible and adaptable methodology for particular teaching contexts.

This versatility of the methodology makes the DBR interesting in different environments and scenarios, whether in primary or higher education, or even for teacher education and development. On the other hand, the fact that the DBR is flexible on different proposals, many variable studies are generated without a major spotlighted area for the use of the methodology and the consolidation movement of a very defined and delimited line of research in the Science Education field.

Lastly, it was verified that the DBR approach is a very favorable and promising methodology to enhance teaching and learning, since it enables educational interventions planned particularly for real-life scenarios of each school according to its unique context. Besides this, the methodology allows to improve the intervention project by a redesign process based on the obtained results. Despite these potentialities, it is worth highlighting that the methodology has been little applied in the field of Science Education, since the 724 published records about DBR between 2003 and 2018, only 65 (9\%) of them are about this theme.

In Brazil, research on DBR is well diversified and without a collaboration group that acts effectively in the area. Brazilian researchers still operate in a very uncoordinated way and on different fronts. However, there are some Brazilian authors starting to publish on DBR and education, with some important contributions, and of the 9 articles with Brazilian authors, 7 were published in the last 3 years. It is also noteworthy that one of these articles was produced for the use of DBR in teaching physics and published in 2019. It is worth mentioning that some Brazilian journals in the field of science education are not covered by the database used. Faced with this, the intention of this study was only to analyze the incidence of Brazilian production within a database of academic productions of global impact as WoS.

This bibliometric mapping of DBR revealed important findings about the most prominent authors, journals, and countries. Therefore, these findings provide insights for future researchers interested in DBR like important keywords, main authors and principal journals. These data also present possible trends and the main characteristics of the works published in the DBR and Science Education interface, as well as challenging issues. 


\section{Acknowledgment}

The authors would like to thank the Federal Institute of Education, Science and Technology of São Paulo (IFSP), Catanduva, the São Paulo State University (Unesp) Institute of Chemistry, Araraquara and the Brazilian Federal Foundation for Support and Assessment of Graduate Education (CAPES).

\section{References}

Amiel, T., \& Reeves, T. C. (2008). Design-based research and educational technology: Rethinking technology and the research agenda. Educational Technology and Society, 11(4), 29-40. https://doi.org/10.2307/jeductechsoci.11.4.29

Anderson, T., \& Shattuck, J. (2012). Design-based research: A decade of progress in education research? Educational Researcher, 41(1), 16-25. https://doi. org/10.3102/0013189X11428813

Andrade, D. F., Romanelli, J. P., \& Pereira-Filho, E. R. (2019). Past and emerging topics related to electronic waste management: Top countries, trends, and perspectives. Environmental Science and Pollution Research, 26(17), 17135-17151. https://doi. org/10.1007/s11356-019-05089-y

Assefa, S. G., \& Rorissa, A. (2013). A bibliometric mapping of the structure of STEM education using co-word analysis. Journal of the American Society for Information Science and Technology, 64(12), 2513-2536. https://doi.org/10.1002/asi.22917

Baker, P. (2004). Querying Keywords Questions of Difference, Frequency, and Sense in Keywords Analysis. Journal of English Linguistics, 32(4), 346-359. https://doi. org/10.1177/0075424204269894

Barab, S. A., Gresalfi, M., \& Ingram-Goble, A. (2011). Transformational play: Using games to position person, content, and context. Educational Researcher, 39(7), 525-536. https://doi.org/10.3102/0013189X10386593

Barab, S., \& Squire, K. (2004). Design-based research: Putting a stake in the ground. The Journal of the Learning Sciences, 13(1), 1-14. https://doi.org/10.1207/s15327809jls1301_1

Batagelj, V., \& Cerinsek, M. (2013). On bibliographic networks. Scientometrics, 96, 845864. https://doi.org/10.1007/s11192-012-0940-1

Batista, R. F. M., \& Silva, C. C. (2019). When Things Go Wrong - Implementing HistoricalInvestigative Activities in the Classroom. Science \& Education, 28(9-10), 1153-1151. https://doi.org/10.1007/s11191-019-00071-z

Brown, A. L. (1992). Design experiments: Theoretical and methodological challenges in creating complex interventions in classroom settings. The Journal of the Learning Sciences, 2(2), 141-178. https://doi.org/10.1207/s15327809jls0202_2

Collins, A. (1992). Towards a design science of education. In E. Scanlon \& T. O’shea (Eds.), New directions in educational technology (pp. 15-22). Springer Verlag. 
Davis, E. A., Palincsar, A. S., Arias, A. M., Bismack, A. S., Marulis, L. M., \& Iwashyna, S. K. (2014). Designing educative curriculum materials: A theoretically and empirically driven process. Harvard Educational Review, 84(1), 24-52. https://doi.org/10.17763/ haer.84.1.g48488u230616264

Design-Based Research Collective. (2003). Design-based research: An emerging paradigm for educational inquiry. Educational Researcher, 32(1), 5-8. https://doi. org/10.3102/0013189X032001005

Diem, A., \& Wolter, S. C. (2013). The use of bibliometrics to measure research performance in education sciences. Research in Higher Education, 54, 86-114. https:// doi.org/10.1007/s11162-012-9264-5

diSessa, A. A., \& Cobb, P. (2004). Ontological innovation and the role of theory in design experiments. The Journal of the Learning Sciences, 13(1), 77-103. https://doi. org/10.2307/1466933

Dunleavy, M., Dede, C., \& Mitchell, R. (2009). Affordances and limitations of Immersive participatory augmented reality simulations for teaching and learning. Journal of Science Education and Technology, 18, 7-22. https://doi.org/10.1007/s10956-008-9119-1

Edelson, D. C. (2002). Design research: What we learn when we engage in design. Journal of the Learning Sciences, 11(1), 105-121. https://doi.org/10.1207/S15327809JLS1101_4

Elleggard, O., \& Wallin, J. A. (2015). The bibliometric analysis of scholarly production: How great is the impact? Scientometrics, 105, 1809-1831. https://doi.org/10.1007/ s11192-015-1645-z

Fishman, B., Marx, R. W., Blumenfeld, P., \& Krajcik, J. (2004). Creating a framework for research on systemic technology innovations. The Journal of the Learning Sciences, 13(1), 43-76. https://doi.org/10.1207/s15327809jls1301_3

Garfield, E. (1990). KeyWords plus: ISI's breakthrough retrieval method. Part 1. Expanding your searching power on current contents on diskette. Current Comments, $32,3-7$.

Garfield, E. (2007). The evolution of the Science Citation Index. International Microbiology, 10, 65-69. https://doi.org/10.2436/20.1501.01.10

Grossman, P., \& McDonald, M. (2008). Back to the Future: Directions for Research in Teaching and Teacher Education. American Educational Research Journal, 45(1), 184205. https://doi.org/10.3102/0002831207312906

Grover, S., Pea, R., \& Cooper, S. (2015). Designing for deeper learning in a blended computer Science course for middle school students. Computer Science Education, 25(2), 199-237. https://doi.org/10.1080/08993408.2015.1033142

Holden, G., Rosenberg, G., \& Barker, K. (2005). Tracing Thought Through Time and Space: A Selective Review of Bibliometrics in Social Work. Social Work in Health Care, 41(3-4), 1-34. https://doi.org/10.1300/J010v41n03_01 
Li, K., Rollins, J., \& Yan, E. (2018). Web of Science use in published research and review papers 1997-2017: A selective, dynamic, cross-domain, content-based analysis. Scientometrics, 115(1), 1-20. https://doi.org/10.1007/s11192-017-2622-5

Looi, C., Sun, D., Wu, L., Seow, P., Chia, G., Wong, L., ... \& Norris, C. (2014). Implementing mobile learning curricula in a grade level: Empirical study of learning effectiveness at scale. Computers and Education, 77, 101-115. https://doi.org/10.1016/j. compedu.2014.04.011

Marton, F., \& Pang, M. F. (2006). On some necessary conditions of learning. The Journal of the Learning Sciences, 15(2), 193-220. https://doi.org/10.1207/s15327809jls1502_2

McNeill, K. L. (2011). Elementary students' views of explanation, argumentation, and evidence, and their abilities to construct arguments over the school year. Journal of Research in Science Teaching, 48(7), 793-823. https://doi.org/10.1002/tea.20430

Narayan, V., Herrington, J., \& Cochrane, T. (2019). Design principles for heutagogical learning: Implementing student-determined learning with mobile and social media tools. Australasian Journal of Educational Technology, 35(3), 86-101. https://doi.org/10.14742/ ajet.3941

Okubo, Y. (1997). Bibliometric indicators and analysis of research systems: methods and examples. OECD Publishing.

Plomp, T. (2013). Educational design research: An introduction. In T. Plomp \& N. Nieveen (Eds.), Educational Design Research - Part A: An introduction (pp. 10-51). Netherlands: SLO Netherlands Institute for Curriculum Development.

Ravenscroft, A. (2007). Promoting thinking and conceptual change with digital dialogue games. Journal of Computer Assisted Learning, 23(6), 453-465. https://doi.org/10.1111/ j.1365-2729.2007.00232.x

Razera, J. C. C. (2015). Un perfil cienciométrico de Revista Eureka sobre Enseñanza y Divulgación de las Ciencias (2004-2013). Revista Eureka sobre Enseñanza y Divulgación de las Ciencias 12(2), 237-248. https://doi.org/10.25267/Rev_Eureka_ensen_divulg_ cienc.2015.v12.i2.01

Reigeluth, C. M. \& Frick, T. W. (1999). Formative research: A methodology for creating and improving design theories. In C. M. Reigeluth (Ed.), Instructional-design theories and models (pp. 633-651). New Jersey: Lawrence Erlbaum.

Richey, R. C., Klein, J. D., \& Nelson, W. A. (2003). Development research: Studies of instructional design and development. In D. H. Jonassen \& M. Driscoll (Eds.), Handbook of research for educational communications and technology (pp. 1099-1130). Routledge.

Rosebery, A. S., Warren, B., \& Tucker-Raymond, E. (2016). Developing interpretive power in science teaching. Journal of Research in Science Teaching, 53(10), 1571-1600. https://doi.org/10.1002/tea.21267 
Schwarz, C. (2009). Developing preservice elementary teachers' knowledge and practices through modeling-centered scientific inquiry. Science Education, 93(4), 720-744. https:// doi.org/10.1002/sce.20324

Seale, C., Charteris-Black, J., MacFarlane, A., \& McPherson, A. (2010). Interviews and internet forums: A comparison of two sources of qualitative data. Qualitative Health Research, 20(5), 595-606. https://doi.org/10.1177/1049732309354094

Shareefa, M., \& Moosa, V. (2020). The most-cited educational research publications on differentiated instruction: A bibliometric analysis. European Journal of Educational Research, 9(1), 331-349. https://doi.org/10.12973/eu-jer.9.1.331

Tiberghien, A., Vince, J., \& Gaidioz, P. (2009). Design-based research: Case of a teaching sequence on mechanics. International Journal of Science Education, 31(17), 2275-2314. https://doi.org/10.1080/09500690902874894

Van den Akker, J. (1999). Principles and methods of development research. In J. van den Akker, R. M. Branch, K. Gustafson, N. Nieveen, \& T. Plomp (Eds.), Design approaches and tools in education and training (pp. 1-14). Kluwer Academic.

Van Eck, P. J., \& Waltman, L. (2010). Software survey: VOSviewer, a computer program for bibliometric mapping. Scientometrics, 84(2), 523-538. https://doi.org/10.1007/ s11192-009-0146-3

Van Eck, P. J., \& Waltman, L. (2017). VOSviewer Manual. Leiden University.

Vanderlinde, R., \& Van Braak, J. (2010). The gap between educational research and practice: Views of teachers, school leaders, intermediaries and researchers. British Educational Research Journal, 36(2), 299-316. https://doi.org/10.1080/01411920902919257

Vesper, J. L., Herrington, J., Kartoglu, U., \& Reeves, T. C. (2015). Initial design principles for establishing a learning community for public health professionals through authentic e-learning. International Journal of Continuing Engineering Education and Life-Long Learning, 25(2), 241-257. https://doi.org/10.1504/IJCEELL.2015.069870

Waltman, L., van Eck, N. J., \& Noyons, E. C. M. (2010). A unified approach to mapping and clustering of bibliometric networks. Journal of Informetrics, 4, 629-635. https://doi. org/10.1016/j.joi.2010.07.002

Wang, F., \& Hannafin, M. J. (2005). Design-based research and technology-enhanced learning environments. Educational Technology Research and Development, 53(4), 5-23. https://doi.org/10.1007/BF02504682

Wang, S. K., \& Reeves, T. C. (2007). The effects of a web-based learning environment on student motivation in a high school earth science course. Educational Technology Research and Development, 55(2), 169-192. https://doi.org/10.1007/s11423-006-9016-3

Zembal-Saul, C. (2009). Learning to teach elementary school science as argument. Science Education, 93(4), 687-719. https://doi.org/10.1002/sce.20325 
Zheng, L. (2015). A systematic literature review of design-based research from 2004 to 2013. Journal of Computers in Education, 2(4), 399-420. https://doi.org/10.1007/s40692015-0036-Z

Zhu, J., \& Liu, W. (2020) A tale of two databases: the use of Web of Science and Scopus in academic papers. Scientometrics, 123, 321-335. https://doi.org/10.1007/s11192-02003387-8

${ }^{\circ}$ Luciana Natália Cividatti Bragueto Universidade Estadual Paulista Júlio de Mesquita Filho (Unesp) - São Paulo State University (Unesp) Institute of Chemistry Araraquara, São Paulo, Brazil Federal Institute of Education, Science and Technology of São Paulo (IFSP) Catanduva, São Paulo, Brazil luciananc@ifsp.edu.br

Vagner Antonio Moralles

Universidade Estadual Paulista Júlio de Mesquita Filho (Unesp) - São Paulo State University (Unesp) Institute of Chemistry Araraquara, São Paulo, Brazil vagnermoralles@hotmail.com

Amadeu Moura Bego

Universidade Estadual Paulista Júlio de Mesquita Filho (Unesp) - São Paulo State University (Unesp) Institute of Chemistry Araraquara, São Paulo, Brazil amadeu.bego@unesp.br

Editor in charge

Stefannie Ibraim

Disclosure statement

No potential conflict of interest was reported by the authors.

Compliance with Ethical Standards

The authors declare this study was conducted following ethical principles. 